\title{
PENGEMBANGAN MEDIA MOTIF (MONOPOLI EDUKATIF) DALAM PEMBELAJARAN BERBASIS MULTIPLE INTELLIGENCE PADA ANAK TK KELOMPOK B
}

\author{
Dwi Nur Meilani Maqfiroh $^{1}$, Khutobah $^{2}$, Luh Putu Indah Budyawati ${ }^{3}$ \\ ${ }^{1,2,3}$ Universitas Jember
}

\begin{abstract}
This development research was conducted at TK Kartika IX-35, Patrang District, Jember Regency in the academic year 2019-2020. The purpose is to describe the process and results of the development of MOTIF (Educative Monopoly) media in multiple-based intelligent learning in group B at TK Kartika IX-35 Patrang, Jember. Data collection techniques used are validation, observation, and questionnaire. This study uses a Borg and Gall type development research model, because this type is used to develop and validate products in the education and learning fields. The stages of the research consisted of identifying the problem, data collection, product design, product design validation, product design revision, product trials, product revision, and the phase of usage testing. The MOTIF (Educative Monopoly) media development test consists of a validity test, a practical test and an effectiveness test. The results of the development of MOTIF (Educative Monopoly) learning media are categorized valid based on the assessment given by expert validators and practitioner validators. Learning is categorized as effective as seen from children's activities that show above-average values, positive teacher responses when teaching using educational monopoly media, and children are more enthusiastic in learning activities. Learning categorized as practical seen from the activities of teachers who showed a percentage above the average of $90 \%$ with good interpretation.
\end{abstract}

Keyword: Learning Media, MOTIF (Educative Monopoly), Multiple intelligences

\begin{abstract}
Abstrak: Penelitian pengembangan ini dilakukan di TK Kartika IX-35 Kecamatan Patrang, Kabupaten Jember tahun pelajaran 2019-2020. Tujuan penelitian ini untuk mendeskripsikan proses dan hasil pengembangan media MOTIF (Monopoli Edukatif) dalam pembelajaran berbasis multiple intelligence pada anak kelompok B di TK Kartika IX-35 Patrang, Jember. Teknik pengumpulan data yang digunakan yaitu validasi, observasi, dan angket/kuisioner. Penelitian ini menggunakan model penelitian pengembangan tipe Borg and Gall, karena tipe ini digunakan untuk mengembangkan dan memvalidasi produk-produk dalam bidang pendidikan dan pembelajaran. Tahapan penelitian terdiri dari tahap mengidentifikasi masalah, tahap pengumpulan data, tahap mendesain produk, tahap validasi desain produk, tahap revisi desain produk, tahap uji coba produk, tahap revisi produk, dan tahap uji coba pemakaian. Uji pengembangan media MOTIF (Monopoli Edukatif) terdiri dari uji validitas, uji kepraktisan, dan uji keefektifan. Hasil pengembangan media pembelajaran MOTIF (Monopoli Edukatif) dikategorikan valid berdasarkan dari penilaian yang diberikan oleh validator ahli dan validator praktisi. Pembelajaran dikategorikan efektif dilihat dari aktivitas anak yang menunjukkan nilai di atas rata-rata, respon guru yang positif ketika mengajar menggunakan media monopoli edukatif, dan anak lebih antusias dalam kegiatan pembelajaran. Pembelajaran dikategorikan praktis dilihat dari aktivitas guru yang menunjukkan persentase di atas rata-rata yaitu $90 \%$ dengan interpretasi baik.
\end{abstract}

Kata Kunci: Media Pembelajaran, MOTIF (Monopoli Edukatif), Kecerdasan Jamak

\footnotetext{
'Universitas Jember, Email: dwinurmeilanimaqfirah gmamail.com

${ }^{2}$ Universitas Jember, Email: khutabahmahtaram.fkip 国unej.ac.id

${ }^{3}$ Universitas Jember, Email: indahbudyawati.fkip回unej.ac.id
} 


\section{PENDAHULUAN}

Usia dini merupakan periode sensitif, selama masa ini anak dengan mudah dapat menerima stimulus dari lingkungannya. Pada usia keemasan anak mulai peka menerima berbagai stimulus dan berbagai upaya pendidikan yang diberikan oleh lingkungannya (Sujiono, 2013). Pendidikan anak usia dini ini berguna untuk menstimulus kecerdasan jamak yang dimiliki anak agar berkembang secara optimal. Berbagai pengetahuan akan mudah diserap anak pada usia dini karena otak anak pada usia dini lebih maksimal dalam menyerap pengetahuan. Pendidik dapat menciptakan suasana belajar yang memacu kreativitas siswa dengan menggunakan media yang mendukung tercapainya tujuan pembelajaran. Menurut Arsyad (2006), media merupakan alat bantu dalam proses belajar mengajar di kelas maupun di luar kelas. Media pembelajaran MOTIF (monopoli edukatif) merupakan media yang dapat menstimulus multiple intelligence berupa alat permainan edukatif. Berdasarkan penjelasan tersebut maka penggunaan media pembelajaran diperlukan untuk menstimulus kecerdasan jamak yang dimiliki anak.

Kecerdasan merupakan rangkaian kemampuan mental, keahlian, bakat dalam memproses jenis informasi tertentu (Gardner, 2013). Multiple intelligence merupakan kecerdasan jamak yang dimiliki oleh setiap anak yang terbagi menjadi 9 kecerdasan yaitu kecerdasan linguistik, kecerdasan visual spasial, kecerdasan musikal, kecerdasan logika matematika, kecerdasan kinestetik, kecerdasan interpersonal, kecerdasan intrapersonal, kecerdasan naturalis, dan kecerdasan spiritual (Hamzah, 2009). Setiap anak yang memiliki kecerdasan tertentu, akan menyelesaikan permasalahan dengan melibatkan kecerdasan tertentu. Terdapat kecerdasan yang lebih menonjol dibandingkan kecerdasan lainnya, akan tetapi beberapa kecerdasan juga dapat berjalan selaras dengan kecerdasan yang lain. Cara mengembangkan kecerdasan jamak pada anak yaitu melalui kegiatan bermain. Menurut Fauziddin (2017), bermain merupakan kebutuhan yang primer bagi anak. Kegiatan bermain dapat merangsang cara berpikir kreatif dan mengembangkan kemampuan intelektual pada anak (Aisyah, 2013). Melalui kegiatan bermain guru memberikan kesempatan pada anak untuk bereksplorasi dan menambah pengalaman ngsung dalam mengatasi permasalahan sederhana.

Unsur pendukung tercapainya pembelajaran yang efektif yaitu bahan/materi, media, suasana kelas, dan metode pembelajaran. Salah satu unsur yang mendukung pembelajaran yaitu media pembelajaran. Media pembelajaran digunakan untuk memudahkan penyampaian tujuan pembelajaran. Menurut Aisyah (2016) dalam penelitiannya mengenai penerapan media kartu bergambar dapat meningkatkan kemampuan berhitung permulaan pada anak kelompok B. Penelitian Wahyunita (2016) menyimpulkan bahwa penerapan media kartu angka dapat meningkatkan kemampuan kognitif anak kelompok A1. Salah satu cara yang baik dalam menyampaikan materi pembelajaran yaitu melalui kegiatan bermain dengan menggunakan media yang menarik minat anak, sehingga anak lebih mudah menyerap pengetahuan .

Trisniwati (2014) menjelaskan penerapan media kartu huruf dapat meningkatkan kemampuan mengenal huruf pada anak kelompok B1. Kegiatan belajar sambil bermain menggunakan media kartu huruf dapat menciptakan suasana belajar yang menyenangkan sehingga memudahkan anak dalam belajar pengenalan huruf. Namun, media kartu huruf terbatas hanya untuk menstimulus kecerdasan linguistik dalam hal pengenalan huruf. Padahal 
kecerdasan jamak anak mencakup 9 kecerdasan yang harus mendapat stimulus pada masing-masing kecerdasannya. Untuk menstimulus kecerdasan jamak anak, pendidik harus memiliki gagasan, inovasi, serta keterampilan dalam membuat media pembelajaran. Media pembelajaran MOTIF (monopoli edukatif) ini merupakan penggabungan dari media kartu huruf, kartu gambar, dan kartu angka yang dimodifikasi dalam bentuk monopoli edukatif sebagai media dalam pembelajaran berbasis multiple intelligence. Menurut Chatib (2017), monopoli merupakan permainan bisnis properti berupa aset bangunan dan tanah, permainan ini menggunakan pion, dadu, kartu tanah mainan, serta uang mainan. Monopoli edukatif ini berbeda dengan monopoli pada umumnya, terdapat unsur yang menstimulus kecerdasan jamak anak, seperti pengenalan huruf, pengenalan angka, pengenalan gambar buah-buahan dan hewan, serta pengenalan warna. Media MOTIF ini dikembangkan untuk menstimulus kecerdasan jamak yang ada pada anak, sehingga semua kecerdasan anak dapat terstimulus dengan baik.

\section{TINJAUAN PUSTAKA}

Kecerdasan jamak yang dimiliki setiap orang berbeda-beda. Jenis-jenis kecerdasan jamak menurut Gardner (2013) terbagi menjadi 9 kecerdasan yaitu: (1) kecerdasan linguistik, merupakan kemampuan menangkap atau peka terhadap bunyi, struktur, kata-kata, dan bahasa. Menurut Susanto (2014), kemampuan bahasa anak dimulai dari menirukan bunyi. Setelah menirukan bunyi, anak akan belajar berbicara. Anak yang memiliki kecerdasan linguistik lebih gemar bercakap-cakap dan bercerita. Selain itu, anak mampu berkomunikasi dengan baik secara lisan maupun tulisan. (2) Kecerdasan logika matematika, merupakan kemampuan anak dalam berpikir logis, menalar, kritis terhadap simbol angka dan hitungan (Chatib, 2017). Anak yang memiliki kecerdasan logika matematika lebih cenderung menyukai hal-hal yang berkaitan dengan perhitungan, memperkirakan, bereksperimen, dan menyusun langkah-langkah kegiatan bermain. (3) Kecerdasan visual spasial, Anak yang memiliki kecerdasan visual spasial tinggi cenderung berpikir secara visual (Sholeh, 2016). Anak dengan tipe kecerdasan ini penuh dengan khayalan, sehingga lebih kreatif dan cenderung imajinatif. Kecerdasan visual spasial dapat divisualisasikan dengan membuat sketsa, gambar simbol, gambar grafik, mengadakan karya wisata di luar kelas, bereksperimen di ruang laboratorium. (4) Kecerdasan kinestetik, mengarah pada kemampuan dalam menggerakkan bagian tubuh sebagai wujud pengekspresian ide dan perasaannya (Sholeh, 2016). Anak dengan kecerdasan kinestetik terampil menggunakan tangan untuk membuat dan memodifikasi sesuatu. Kecerdasan kinestetik ini diekspresikan dalam bentuk gerakan. (5) Kecerdasan musikal, merupakan kemampuan peka anak terhadap irama, nada, ritme, serta bentukbentuk ekspresi musik (Chatib, 2017). Kecerdasan musikal dapat dideteksi melalui kegiatan pembelajaran di sekolah seperti mengamati kesenangan anak didalam kelas, seperti bernyanyi, bersiul, bertepuk tangan, mengetuk meja untuk menghasilkan bunyi, dan menghentakkan kaki (Musfiroh, 2014). (6) Kecerdasan intrapersonal, mengarah pada kemampuan seseorang peka terhadap perasaan yang ada pada dirinya sendiri (Mifzal, 2014, hlm. 59). Orang dengan kecerdasan ini mampu memahami kelemahan serta kelebihan yang ada pada dirinya. Orang yang memiliki keterampilan emosi yang baik, kemungkinan besar akan bahagia dan berhasil dalam kehidupannya (Nugraha dan Rachmawati, 2014). Hal itu dikarenakan orang dengan keterampilan sosial emosional yang baik dapat 
mengontrol pikiran dan mendorong produktivitasnya. (7) Kecerdasan Interpersonal, merujuk pada kemampuan seseorang yang memiliki kepekaan terhadap perasaan orang lain (Mifzal, 2014). Seseorang dengan kecerdasan interpersonal dapat memahami dan berinteraksi dengan orang lain. Orang yang memiliki kecerdasan interpersonal yang baik lebih mudah bersosialisasi dengan lingkungan sekitarnya.

Kecerdasan naturalis, merupakan kemampuan anak dalam mengamati gejala alam, membedakan suatu spesies tertentu, mengenali keberadaan spesies lain (Chatib, 2017). Anak dengan kecerdasan ini menyukai kegiatan mengamati dan berinteraksi dengan lingkungan alam, dan lebih peduli pada hewan maupun tumbuhan.

Kecerdasan spiritual, merupakan kecerdasan yang mengangkat fungsi jiwa yang berperan sebagai perangkat internal dalam diri (Asteria, 2014). Menurut Fauziddin (2017), kecerdasan spiritual pada anak dapat diasah melalui pembelajaran tentang pengetahuan keagamaan, keterampilan keagamaan, pengalaman keagamaan, keyakinan keagamaan, dan penghayatan keagamaan. Menurut Kumojoyo (2011), kecerdasan jamak dipengaruhi oleh beberapa faktor yaitu: (1) faktor hereditas yang mencakup faktor pewarisan atau biologis dari orang tua yang dibawa anak sejak lahir. Faktor pewarisan ini meliputi kecerdasan, kemampuan seni, kemampuan memimpin, dan psikomotor (Marpaung, 2017). Faktor hereditas mempengaruhi perkembangan kecerdasan jamak pada anak, anak yang memiliki kecacatan mental atau kecacatan fisik dari lahir membutuhkan lebih banyak latihan untuk mengembangkan kecerdasan yang dimilikinya. (2) Faktor lingkungan keluarga, merupakan faktor yang membentuk kecerdasan jamak dari keadaan di luar diri. Dorongan dari lingkungan keluarga mempengaruhi rasa kepercayaan diri anak dengan kemampuan yang dimilikinya. (3) Faktor kesehatan, pemenuhan kebutuhan makanan bergizi diperlukan untuk menunjang kesehatan fisik maupun mental anak. (4) Faktor lingkungan sekolah, merupakan pembentukan kecerdasan jamak dibentuk dari keadaan di luar diri. Kecerdasan jamak dapat dibentuk dari adanya proses belajar di sekolah dengan kegiatan yang menarik yang dapat mendorong anak untuk belajar serta mengembangkan kecerdasan jamak yang dimilikinya. Media pembelajaran bermanfaat untuk menarik minat belajar siswa sehingga dapat menumbuhkan motivasi belajar siswa (Sanaky, 2013). Penggunakan media pembelajaran juga dapat mempermudah guru dalam menyampaikan pembelajaran yang lebih bervariasi dan tidak monoton. Siswa mendapatkan pengalaman langsung dengan adanya media pembelajaran yang digunakan. Menurut (Syamsuardi, 2012) alat permainan edukatif dirancang sebagai alat bantu belajar yang dapat mengoptimalkan perkembangan anak, sesuai tingkat usia dan tingkat perkembangannya. Menurut Media Pembelajaran MOTIF (Monopoli Edukatif) ini mengandung unsur edukatif yang dapat mengembangkan kecerdasan jamak pada anak.

Kecerdasan akan berkembang apabila memperoleh pengajaran dan dukungan (Musfiroh, 2014). Kecerdasan bisa terbentuk apabila seseorang terlibat dalam kegiatan yang mengikuti pola tertentu. Pengalaman bisa diperoleh dari adanya stimulus yang diberikan pada anak usia dini karena pada pendidikan anak usia dini terjadi proses pengasuhan, pendidikan, serta pengajaran (Musfah, 2012). Menurut Mifzal (2014), kecerdasan jamak pada umumnya bekerja secara bersamaan dengan cara yang kompleks. Pada aktivitas sehari-hari, kecerdasan yang dimiliki anak tidak berdiri sendiri. Kecerdasan satu dengan yang kecerdasan lain akan saling 
berkaitan. Munculnya kecerdasan jamak pada anak ditandai dengan melakukan kegiatan yang disukainya, karena setiap manusia mempunyai kecerdasan yang berbeda-beda. Walaupun ada perbedaan pengelompokkan jenis kecerdasan, namun semua kecerdasan itu sederajat. Tidak ada nilai kecerdasan satu lebih tinggi dari kecerdasan lainnya. Kecerdasan satu dengan lainnya memiliki kadar yang berbeda-beda pula. Masingmasing kecerdasan punya peranan sendiri-sendiri dalam kehidupan manusia.

\section{METODOLOGI PENELITIAN}

Jenis penelitian yang digunakan adalah penelitian pengembangan dengan menggunakan model pengembangan tipe Borg and Gall yang diadaptasi menjadi 8 tahapan yaitu: mengidentifikasi masalah, mengumpukan data, mendesain produk, validasi desain produk, revisi desain produk, uji coba produk pada kelompok kecil, revisi produk, dan uji coba produk pada kelompok besar (Sugiyono, 2015). Subjek penelitian adalah anak kelompok B di TK Kartika IX-35 Patrang Jember. Teknik pengumpulan data yang digunakan yaitu validasi, observasi, dan angket/kuisioner. Instrumen penelitiannya berupa lembar validasi media, lembar kerja anak, lembar penilaian aktivitas belajar anak, lembar pengamatan aktivitas guru, dan lembar angket respon guru terhadap pembelajaran. Teknik analisis yang digunakan yaitu teknik analisis data kevalidan media, analisis kepraktisan penggunaan media, dan analisis keefektifan media dengan menggunakan persentase ketercapaian indikator kecerdasan jamak dari pengamatan aktivitas belajar anak.

\section{HASIL PENELITIAN DAN PEMBAHASAN$$
\text { Hasil Penelitian }
$$$$
\text { Berdasarkan hasil dari }
$$ mengidentifikasi masalah, permasalahan muncul karena sekolah sebenarnya}

mempunyai potensi bagus untuk mengembangkan kecerdasan jamak anak namun potensi tersebut belum dikelola dengan baik. Permasalahan yang ditemukan ketika melakukan pengamatan di kelas yaitu media pembelajaran masih belum optimal dalam menstimulus kecerdasan jamak yang dimiliki anak. Selain itu, permasalahan lainnya yaitu kurangnya alat permainan edukatif dalam kelas. Guru sering kali menyampaikan materi pembelajaran hanya dengan media gambar yang digambar pada papan tulis. Setelah mengetahui permasalahan yang ada di sekolah, maka selanjutnya perlu mengumpulkan berbagai informasi dan data yang dapat digunakan sebagai bahan acuan dalam merencanakan pembuatan produk tertentu yang diharapkan mampu mengatasi permasalahan yang ada. Pada tahap pengumpulan data, peneliti mengumpulkan data berupa tingkat pencapaian kecerdasan jamak anak yang didapat dari mengidentifikasikan STPPA sesuai dengan kecerdasan jamak anak dan tahapan usia anak 5-6 tahun.

Tahap selanjutnya, mendesain produk pendidikan berbentuk media pembelajaran MOTIF (monopoli edukatif) yang mempunyai manfaat mengembangkan kecerdasan jamak, diantaranya: (1) kecerdasan linguistik, anak bisa belajar huruf alfabet yang ada pada setiap kotak, belajar mengeja nama buah, nama benda, dan nama hewan; (2) kecerdasan logika matematika, anak belajar menghitung jumlah gambar buahbuahan, dan gambar benda disekitar; (3) kecerdasan visual spasial, anak belajar menebak gambar dan menebak warna buah yang ada di kartu pertanyaan/kartu kuning; (4) kecerdasan kinestetik, anak bisa belajar dengan melakukan gerakan bertepuk tangan sesuai irama, dan bernyanyi dengan gerakan ketika berhenti di kotak lagu; (5) kecerdasan musikal, anak belajar mengekspresikan diri melalui kegiatan menyanyikan lagu yang ada di kartu tantangan/kartu hijau; (6) kecerdasan spiritual, anak bisa belajar 
membaca doa sehari-hari dan surat-surat pendek (bagi yang beragama muslim); (7) kecerdasan interpersonal, anak dapat berinteraksi dengan teman sebayanya dan melatih kemampuan dalam berkomunikasi; (8) kecerdasan intrapersonal, anak mengetahui kapan gilirannya bermain dan bergantian dengan pemain lainnya, menumbuhkan kesadaran akan tanggung jawabnya menyelesaikan tugas yang diberikan guru, serta menyelesaikan misi pada kartu tantangan dan kartu pertanyaan yang ada dalam media MOTIF; (9) kecerdasan naturalis, anak menyebutkan jenis buah-buahan, serta mengelompokkan jenis hewan berdasarkan jumlah kaki dan ciri-cirinya.

Teknik analisis data merupakan teknik mengolah data yang didapat dari penelitian dan digunakan untuk menjawab pertanyaan mengenai produk yang telah dikembangkan apakah sudah memenuhi kriteria kevalidan, kepraktisan, dan kefektifan (Hobri, 2010). Tahap uji validitas dilakukan dengan menganalisis data kevalidan diperoleh dari hasil validasi media pembelajaran MOTIF (monopoli edukatif). Proses validasi dilakukan dengan menyerahkan lembar instrumen validasi media MOTIF (monopoli edukatif) kepada validator yang terdiri dari dua tenaga ahli yaitu dosen PG PAUD FKIP Universitas Jember yang ahli dalam bidang media pembelajaran dan guru kelas B TK Kartika IX-35 Patrang, Jember selaku validator dari praktisi. Setiap tenaga ahli diminta untuk menilai produk tersebut, sehingga dapat diketahui kelemahan dan kelebihan dari produk yang dirancang. Validasi desain produk dilakukan dengan memberi skor 1 sampai 4 pada masing-masing poin yang akan dinilai. Berdasarkan analisis data validasi media yang diberikan oleh masing-masing validator, kemudian direkap dalam tabel berikut.
Tabel 4.1 Hasil Validasi Instrumen Media Pembelajaran MOTIF (Monopoli Edukatif)

\begin{tabular}{|l|l|c|c|c|}
\hline No & $\begin{array}{c}\text { Aspek } \\
\text { Penilaian }\end{array}$ & V1 & V2 & Mean \\
\hline 1. & Segi edukatif & 3,5 & 3,1 & 3,3 \\
\hline 2. & Segi teknik & 3,3 & 2,8 & 3,05 \\
\hline 3. & Segi estetika & 3,6 & 3 & 3,3 \\
\hline \multicolumn{4}{|c|}{ Rata-rata } & 3,2 \\
\hline
\end{tabular}

Hasil skor rata-rata validasi secara keseluruhan adalah 3,2. Berdasarkan kriteria kevalidan, media pembelajaran MOTIF (monopoli edukatif) yang digunakan dalam penelitian telah memenuhi syarat kevalidan.

Tahap uji keefektifan ditinjau dari beberapa hal, yaitu menganalisis hasil pengamatan aktivitas anak ketika pembelajaran, dan ketercapaian indikator kecerdasan jamak. Pengamatan yang dilakukan guna untuk mengukur tingkat penguasaan siswa dalam mencapai tujuan pembelajaran yang telah ditentukan sesuai kompetensi dasar yang harus dicapai anak. Keefektifan produk dapat dinilai dari data yang diperoleh saat kegiatan pembelajaran dengan menggunakan media MOTIF (monopoli edukatif). Hasil observasi penggunaan media MOTIF sebagai berikut.

Tabel 4.2 Hasil Pengamatan Aktivitas Belajar Anak

\begin{tabular}{|l|l|c|c|}
\hline No & \multicolumn{1}{|c|}{ Kategori } & $\begin{array}{c}\text { Jumlah } \\
\text { Anak }\end{array}$ & $\begin{array}{c}\text { Persentase } \\
(\%)\end{array}$ \\
\hline 1. & $\begin{array}{l}\text { Belum } \\
\text { Berkembang }\end{array}$ & 0 & $0 \%$ \\
\hline 2. & $\begin{array}{l}\text { Mulai } \\
\text { Berkembang }\end{array}$ & 0 & $0 \%$ \\
\hline 3. & $\begin{array}{l}\text { Berkembang } \\
\text { Sesuai } \\
\text { Harapan }\end{array}$ & 1 & $5,3 \%$ \\
\hline 4. & $\begin{array}{l}\text { Berkembang } \\
\text { Sangat Baik }\end{array}$ & 18 & $94,7 \%$ \\
\hline Jumlah & 19 & $100 \%$ \\
\hline
\end{tabular}

Hasil uji coba penggunaan media MOTIF dalam pembelajaran berbasis multiple intelligence pada kelompok besar dilakukan dengan sampel 19 anak di kelompok $\mathrm{B}$, terdapat 1 anak dengan persentase $5,3 \%$ yang mendapat skor dalam kategori berkembang sesuai 
harapan (BSH), dan 18 anak dengan persentase $94,7 \%$ mendapat skor dalam kategori berkembangan sangat baik (BSB). Berdasarkan tingkat penguasaan siswa, interpretasi rata-rata skor yang diperoleh anak kelompok B sangat tinggi dengan persentase $\geq 90 \%$.

Berikut adalah tabel perolehan skor rata-rata kelas pada masing-masing indikator pencapaian kecerdasan jamak.

Tabel 4.3 Ketercapaian Indikator Kecerdasan Jamak Anak

\begin{tabular}{|l|l|c|c|}
\hline No & \multicolumn{1}{|c|}{ Indikator } & $\begin{array}{c}\text { Skor } \\
\text { Rata- } \\
\text { Rata } \\
\text { Kelas }\end{array}$ & $\begin{array}{c}\text { Persentase } \\
(\%)\end{array}$ \\
\hline 1. & $\begin{array}{l}\text { Kecerdasan } \\
\text { linguistik }\end{array}$ & 3,8 & $95 \%$ \\
\hline 2. & $\begin{array}{l}\text { Kecerdasan } \\
\text { logika } \\
\text { matematika }\end{array}$ & 3,7 & $92,5 \%$ \\
\hline 3. & $\begin{array}{l}\text { Kecerdasan } \\
\text { visual spasial }\end{array}$ & 3,8 & $95 \%$ \\
\hline 4. & $\begin{array}{l}\text { Kecerdasan } \\
\text { kinestetik }\end{array}$ & 3,7 & $92,5 \%$ \\
\hline 5. & $\begin{array}{l}\text { Kecerdasan } \\
\text { musikal }\end{array}$ & 3,7 & $92,5 \%$ \\
\hline 6. & $\begin{array}{l}\text { Kecerdasan } \\
\text { spiritual }\end{array}$ & 3,7 & $92,5 \%$ \\
\hline 7. & $\begin{array}{l}\text { Kecerdasan } \\
\text { interpersonal }\end{array}$ & 3,8 & $95 \%$ \\
\hline 8. & $\begin{array}{l}\text { Kecerdasan } \\
\text { intrapersonal }\end{array}$ & 3,2 & $80 \%$ \\
\hline 9. & $\begin{array}{l}\text { Kecerdasan } \\
\text { naturalis }\end{array}$ & 3,7 & $92,5 \%$ \\
\hline $\begin{array}{l}\text { Rata-rata total } \\
\text { indikator }\end{array}$ & 3,68 & $92,1 \%$ \\
\hline & & & \\
\hline
\end{tabular}

Rata-rata pada masing-masing kecerdasan mencapai persentase diatas $90 \%$, persentase yang didapat dari skor keseluruhan pada indikator kecerdasan intrapersonal yaitu $80 \%$. Hal itu menunjukkan bahwa pada indikator kecerdasan intrapersonal ini, ada anak yang sudah mampu bertanggung jawab menyelesaikan tugas yang diberikan guru, tetapi masih perlu dilatih rasa tanggung jawabnya dalam hal merapikan alat permainan setelah digunakan.

Tahap uji kepraktisan dilakukan dengan menganalis hasil pengamatan aktivitas guru ketika mengajar, dan juga respon guru setelah menggunakan media
MOTIF. Pengamatan aktivitas guru dinilai berdasarkan indikator kegiatan yang dilakukan guru ketika pembelajaran. Berikut tabel hasil pengamatan aktivitas guru dalam pembelajaran.

Tabel 4.4 Hasil Pengamatan Aktivitas Guru

\begin{tabular}{|l|l|c|c|}
\hline No & \multicolumn{1}{|c|}{ Kegiatan } & Skor & $\begin{array}{c}\text { Persentase } \\
(\%)\end{array}$ \\
\hline 1. & Kegiatan awal & 4 & $100 \%$ \\
\hline 2. & Kegiatan inti & 3,4 & $85 \%$ \\
\hline 3. & Kegiatan penutup & 3,6 & $90 \%$ \\
\hline \multicolumn{2}{|l|}{ Rata-rata } & 3,6 & $90 \%$ \\
\hline
\end{tabular}

Skor yang diperoleh pada masing-masing indikator aktivitas mengajar guru yaitu 3,6 dengan persentase $90 \%$ dapat dikatakan bahwa aktivitas mengajar guru di kelompok B mencapai kriteria sangat baik.

Data respon guru diperoleh dari guru dengan mengisi angket/kuisioner setelah proses pembelajaran selesai. Angket respon berisi tanggapan guru setelah menggunakan media pembelajaran MOTIF (monopoli edukatif) dalam pembelajaran berbasis multiple intelligence. Berikut tabel rekapitulasi hasil respon guru terhadap pembelajaran.

Tabel 4.5 Angket Respon Guru Terhadap Pembelajaran

\begin{tabular}{|l|l|c|c|}
\hline No & $\begin{array}{l}\text { Uraian Pelaksanaan } \\
\text { Pembelajaran }\end{array}$ & Skor & $\begin{array}{c}\text { Persentase } \\
(\%)\end{array}$ \\
\hline 1. & $\begin{array}{l}\text { Rencana } \\
\text { Pelaksanaan } \\
\text { Pembelajaran } \\
\text { Harian (RPPH) }\end{array}$ & 3 & $75 \%$ \\
\hline 2. & $\begin{array}{l}\text { Kesesuaian materi } \\
\text { pembelajaran }\end{array}$ & 3 & $75 \%$ \\
\hline 3. & $\begin{array}{l}\text { Media MOTIF dapat } \\
\text { mengembangkan } \\
\text { multiple intelligence }\end{array}$ & 4 & $100 \%$ \\
\hline 4. & $\begin{array}{l}\text { Kegiatan } \\
\text { pembelajaran }\end{array}$ & 3 & $75 \%$ \\
\hline Rata-rata & 3,25 & $81,25 \%$ \\
\hline
\end{tabular}

Persentase rata-rata respon guru yang diperoleh yaitu $81,25 \%$. Berdasarkan kriteria tingkat respon guru, interpretasi rata-rata skor yang diperoleh sangat baik. 


\section{Pembahasan}

Pada saat dilakukan uji coba produk, kegiatan pertama yang dilakukan yaitu perkenalan dengan anak, mengamati karakter anak, bercakapcakap tentang tema tanaman dengan sub tema sayuran, memberikan kegiatan appersepsi dengan cara bernyanyi tentang macam-macam sayuran. Setelah itu mengenalkan gambar sayuran kepada anak, lalu bertanya kepada anak mengenai sayuran yang bisa dikonsumsi. Selanjutnya anak diberi lembar kerja dengan melengkapi huruf pada nama sayuran, menghitung jumlah sayuran, dan kolase bagian-bagian sayuran tomat.

Setelah anak menyelesaikan tugas pada lembar kerja, guru memberi penjelasan mengenai cara memainkan permainan MOTIF (monopoli edukatif) dan aturan yang harus dipatuhi ketikan bermain. Langkah pertama anak melakukan 'hompimpah' untuk menentukan gilirannya bermain. Pemain 1 melempar dadu yang terbuat dari kain flanel sehingga aman untuk anak. Langkah kedua anak menjalankan pion sesuai dengan angka yang muncul pada dadu. Jika anak berhenti pada kotak huruf, anak diminta menyebutkan huruf apa yang ada dikotak tersebut. Jika anak berhenti pada kotak kuning, maka anak diminta mengambil kartu kuning yang di dalamnya terdapat kartu pertanyaan, kemudian anak menjawab pertanyaan yang ada pada kartu tersebut. Pertanyaan yang ada pada kartu kuning tersebut bermacam-macam seperti menyebutkan ciri-ciri hewan, menghitung jumlah sayuran, menyebutkan hewan berkaki 2 atau berkaki empat, dan menyebutkan ciri buah-buahan. Sedangkan pada kartu hijau berisi tantangan, seperti membaca doa yang ada pada kegiatan sehari-hari, membaca surat-surat pendek, dan menyanyikan lagu yang sudah ditentukan pada kartu hijau. Anak sangat antusias dan bersemangat ketika bermain MOTIF, ada beberapa anak yang masih perlu diingatkan cara bermainnya.
MOTIF (monopoli edukatif) merupakan media pembelajaran yang berbentuk alat permainan edukatif yang dimainkan menggunakan pion, dadu, kartu monopoli, serta papan monopoli. MOTIF ini dikembangkan sebagai media dalam pembelajaran berbasis multiple intelligence pada anak kelompok B di TK Kartika IX-35 Patrang, Jember. Cara memainkan MOTIF ini sama dengan permainan monopoli pada umumnya, hanya saja papan monopoli dan kartu monopoli dimodifikasi agar dapat mengembangkan kecerdasan jamak pada anak dalam pembelajaran berbasis multiple intelligence. Pembelajaran berbasis multiple intelligence merupakan pembelajaran yang lebih berfokus pada pengembangan kecerdasan jamak yang dimiliki oleh anak. Setiap kegiatan pembelajaran dilaksanakan untuk menstimulus kecerdasan jamak pada anak agar semua kecerdasan anak dapat berkembang dengan baik, tidak hanya berkembang pada salah satu kecerdasan saja. Kegiatan pembelajaran berbasis multiple intelligence tersebut diterapkan pada anak kelompok B dengan menggunakan media pembelajaran yang mampu mengembangkan kecerdasan jamak yang ada pada anak.

\section{KESIMPULAN}

Berdasarkan hasil pengembangan dapat disimpulkan bahwa, media pembelajaran MOTIF (monopoli edukatif) telah memenuhi untuk kategori valid, praktis, dan efektif. Skor validasi media pembelajaran MOTIF (monopoli edukatif) dapat dikategorikan valid dengan perolehan skor rata-rata adalah 3,2 sehingga dapat diterapkan pada uji coba kelompok besar. Media pembelajaran MOTIF (monopoli edukatif) dapat dikategorikan praktis. Data kepraktisan ini diperoleh dari data aktivitas guru yang dapat diamati ketika proses pembelajaran berlangsung, dan juga dari angket respon guru terhadap pembelajaran yang memperoleh 
persentase sebanyak 81,25\%. Respon guru ketika mengajar menggunakan media monopoli edukatif menunjukkan hasil positif, dan anak lebih antusias dalam kegiatan pembelajaran. Perolehan skor aktivitas guru ketika pembelajaran yaitu 3,6 dengan persentase $90 \%$ yang dikategorikan baik. Media pembelajaran MOTIF (monopoli edukatif) dapat dikatakan efektif berdasarkan kriteria yaitu: 1) tingkat penguasaan siswa lebih dari $80 \%$ memperoleh nilai tuntas diatas rata-rata, dan 2) ketercapaian indikator pencapaian pembelajaran yang memperoleh hasil 3,68 dengan interpretasi tinggi. Media MOTIF (monopoli edukatif) diharapkan dapat menjadi bahan pertimbangan dalam pembuatan media pembelajaran yang menyenangkan sekaligus menstimulus kecerdasan jamak yang dimiliki anak.

\section{DAFTAR PUSTAKA}

Aisyah, K. N. (2016). Peningkatan Kemampuan Berhitung Permulaan Melalui Media Kartu Bergambar pada Anak Kelompok A2 di TK Jember Permai 1 Kecamatan Sumbersari Kabupaten Jember Tahun Pelajaran 2015/2016. Skripsi. Jember: Fakultas Keguruan dan Ilmu Pendidikan Universitas Jember

Aisyah, S., dkk. (2013). Perkembangan dan Konsep Dasar Pengembangan Anak Usia Dini. Tanggerang Selatan: Universitas Terbuka

Arsyad, A. (2006). Media Pembelajaran. Jakarta: PT Raja Grafindo Persada

Asteria, P. V. (2014). Mengembangkan Kecerdasan Spiritual Anak Melalui Pembelajaran Membaca Sastra. Malang: Universitas Brawijaya Press

Chatib, M. (2017). Semua Anak Bintang: Menggali Kecerdasan dan Bakat
Terpendam dengan Multiple intelligences Research (MIR). Bandung: Kaifa

Fauziddin, M. (2017). Pembelajaran PAUD Bermain, Cerita, dan Menyanyi Secara Islami. Bandung: PT Remaja Rosdakarya Offset

Gardner, H. (2013). Multiple intelligences. Jakarta: Daras Books

Hamzah, A. (2009). Teori Multiple intelligences dan Implikasinya Terhadap Pengelolaan Pembelajaran. Tadris. 4(2): 253254. Serial Online http://ejournal.stainpamekasan.ac. id/index.php/tadris/article/downlo ad/256/247 [Diakses pada 4 Juli 2019 pukul $20.30 \mathrm{WIB}]$

Hobri. (2010). Metodologi Penelitian Pengembangan (Aplikasi pada Penelitian Matematika). Jember: Pena Salsabila

Kumojoyo, A. (2011). Pengaruh Pola Asuh Orang Tua Terhadap Kecerdasan Majemuk Siswa SD. Jakarta: Universitas Islam Negeri Syarif Hidayatullah. Serial Online repository.uinjkt.ac.id/dspace/bitst ream/123456789/5894/1/AGUNG \%20KUMOJOYO-FPS.PDF

[Diakses pada 16 November 2019 pukul 14.45 WIB]

Marpaung, J. (2017). Pengaruh Pola Asuh Terhadap Kecerdasan Majemuk Anak. Batam: Universitas Riau Kepulauan Batam. Jurnal Kopasta (Konseling Pancawaskita). 4(1): 11. Serial Online http://www.journal.unrika.ac.id/ index.php/kopastajounal/article/vi ew/1118/891 [Diakses pada 16 November 2019 pukul 14.30 WIB]

Mifzal, A. (2014). Strategi Pembelajaran untuk Anak Kurang Berprestasi. Yogyakarta: Javalitera 
Musfah, J. (2012). Pendidikan Holistik Pendekatan Lintas Perspektif. Jakarta: Kencana Prenada Media Grup

Musfiroh, T. (2014). Pengembangan Kecerdasan Majemuk. Jakarta: Universitas Terbuka. PAUD4404 (Modul 1). Serial Online http://repository.ut.ac.id/ 4713/1/PAUD4404-M1.pdf

[Diakses pada 13 Juli 2019 pukul 16.35 WIB]

Nugraha, A. dan Y. Rachmawati. (2014). Metode Pengembangan Sosial Emosional. Edisi pertama. Tanggerang selatan: Universias Terbuka

Sanaky, H. AH. (2013). Media Pembelajaran Interaktif-Inovatif. Yogyakarta: Kaukaba Dipantara

Sholeh, K., dkk. (2016). Kecerdasan Majemuk Berorientasi pada Peserta Didik. Yogyakarta: Pustaka Pelajar

Sugiyono. (2015). Metode Penelitian \& Pengembangan (Research and Development). Bandung: Alfabeta

Sujiono, Y. N. (2013). Konsep Dasar Pendidikan Anak Usia Dini. Jakarta: PT Indeks

Susanto, A. (2014). Perkembangan Anak Usia Dini. Jakarta: PT Indeks

Syamsuardi. (2012). Penggunaan Alat Permainan Edukatif (APE) Di Taman Kanak-Kanak PAUD Polewali Kecamatan Tanete Riattang Barat Kabupaten Bone. Jurnal Publikasi Pendidikan. 2(1): 61. Serial Online ojs.unm.ac.id/index.php/pubpend/ article/download/1586/648

[Diakses pada 13 Oktober 2019 pukul 01.58 WIB]

Trisniwati. (2014). Peningkatan Kemampuan Mengenal Huruf Melalui Metode Permainan Kartu Huruf pada Kelompok B1 TK ABA Ketanggungan Wirobrajan Yogyakarta. Skripsi. Yogyakarta:
Fakultas Ilmu Pendidikan Universitas Negeri Yogyakarta.

Wahyunita, M. (2016). Peningkatan

Kemampuan Kognitif Anak

Kelompok Al Melalui Media

Kartu Angka di TK ABA III Ampel

Wuluhan Kecamatan Wuluhan

Kabupaten Jember Tahun

Pelajaran 2015/2016. Skripsi.

Jember: Fakultas Keguruan dan

Ilmu Pendidikan Universitas Negeri Jember. 